\title{
PENGARUH AGENSI HAYATI TERHADAP TANAMAN BAWANG MERAH (Allium
} ascalonicum L.)

\author{
Yayun Farikha Rusdiana ${ }^{1}$, Siwitri Munambar ${ }^{2}$, Anang Sucahyo ${ }^{1}$ \\ ${ }^{1}$ Dinas pertanian dan pangan Pangan Kulonprogo \\ ${ }^{2}$ Politeknik Pembangunan Pertanian Yogyakarta Magelang \\ email : yayunfarikha@gmail.com
}

\begin{abstract}
Biological agents as one of the alternatives that are environmentally friendly control and in accordance with the guidelines of IPM is still not implemented. The purpose of this study to determine the interaction of dose and concentration of biological agents on the growth and yield of onion as well as to the intensity of the disease on onion crop, effect of the use of biological agents Trichoderma sp on growth, onion, and diseases of the onion crop, the concentration of PGPR right for growth and onion as well as against diseases of the onion crop. Fieldwork was arranged in a randomized block design Complete (RAKL) two factors, one control and three replications. The first factor is the dose of Trichoderma harsianum (T) consists of two levels ie: T0: Without Trichoderma harsianum L, T1: Trichoderma harsianum L. dose of $50 \mathrm{~kg}$ / ha $(5 \mathrm{mg} / \mathrm{m} 2)$. The second factor is the concentration of PGPR $(P)$ consists of 4 levels: P0: Without PGPR, P1: PGPR concentration of 2\%, Q2: PGPR concentration of 4\%, P3: PGPR concentration of $6 \%$. The results showed no interaction between dose and concentration on the intensity of fusarium wilt, growth variables dry weight per hill, tuber crops variable dry weight per hectare. The highest efficacy for controlling diseases in onion combination treatment without the use of Trichoderma sp and PGPR concentration of $0 \%$. PGPR concentration of 6\% gave the highest yield of the dry weight of tuber crop yield of 12.7 tonnes per hectare.
\end{abstract}

Keywords: Onion plant, Agensia conservation, Intensity of disease

\section{PENDAHULUAN}

Bawang merah (Allium ascalonicum L.) merupakan salah satu komoditas sayuran unggulan nasional yang fluktuatif harga maupun produksinya. Bawang merah merupakan komoditas strategis karena merupakan kebutuhan pokok masyarakat dan harga mempengaruhi tingkat inflasi (Simatupang, 2004). Kandungan senyawa bawang merah sangat beragam, di antaranya lemak, protein, kalsium, fosfor, besi, vitamin B1 dan vitamin C. Kegunaan bawang merah juga untuk bumbu masak. Dengan banyaknya manfaat bawang merah menjadikan pasar bawang merah sangat terbuka luas, baik di dalam maupun luar negeri, sehingga diperlukan produk bawang merah yang mempunyai kualitas baik dan aman konsumsi (Batubara, 2013).

Harga bawang merah yang fluktuatif menjadi faktor penentu usaha tani bawang merah, dimana bila produksi tinggi saat panen raya maka harga turun. Untuk mencegah terjadinya fluktuasi produksi dan harga yang sering merugikan petani, maka perlu diupayakan budidaya yang dapat berlangsung sepanjang tahun antara lain melalui budidaya di luar musim (off season). Salah satu strategi petani, untuk hal tersebut adalah menanam bawang merah dimulai pada bulan Januari atau Februari (Shofiyani dan Suyadi, 2014).

Kehilangan hasil bawang merah akibat serangan Organisme Pengganggu Tanaman (OPT) masih tinggi. Penyakit layu fusarium 
merupakan salah satu penyakit yang sering menyerang bawang merah. Intensitas serangan pada tanaman menentukan hasil bawang merah. Penurunan hasil bawang merah akibat serangan penyakit trotol 58 $\%$, ulat bawang $32 \%$, dan antraknose 24 - $100 \%$, apabila intensitas serangan lebih dari $21 \%$ (Nirwanto, 2011). Menurut Standar Operasional Prosedur (SOP) Bawang Merah tahun 2010, potensial produktivitas hasil bawang merah lebih dari 12 ton per hektar umbi kering pada musim penghujan, 25 ton per hektar pada musim kemarau. Diameter umbi 2-3 cm, keseragaman bentuk dan warna umbi mencapai minimal $90 \%$.

Data produksi nasional bawang merah berkisar 1 juta ton per tahun, dan kebutuhan nasional sekitar 620 ribu ton/tahun. Rata-rata produktivitas bawang merah di Indonesia masih tergolong rendah, yaitu 4,4 - 14 ton per hektar, sedangkan potensi hasil bawang merah 20 - 25 ton pe hektar (Kafrawi et al., 2015). Varitas bawang merah yang digunakan petani kecamatan Galur Kulon Progo adalah varitas Siam lokal dengan potensi hasil umbi kering 15-20 ton per hektar. Data rata-rata produktivitas bawang merah di Kabupaten Kulon Progo tahun 2012 sebesar 7,9 ton per hektar, tahun 2013 sebesar 7,7 ton per hektar, tahun 2014 sebesar 7,67 ton per hektar (Dipertahut KP, 2014).

Perlindungan tanaman dalam pertanian merupakan komponen yang cukup menentukan keberhasilan dalam usaha tani. Salah satu tindakan pengendalian adalah dengan prinsip Pengendalian Hama Terpadu (PHT), yaitu pendekatan ekologi yang memadukan beberapa teknik pengendalian secara kompatibel dalam satu kesatuan koordinasi sistem pengelolaan (Prabaningrum, 2015). Salah satu prinsip PHT adalah pelestarian musuh alami, dimana pengendalian pathogen pada bawang merah dengan menggunakan agensia hayati dari jamur Trichoderma spp. Jamur ini dapat menjadi parasit pada beberapa jenis jamur penyebab penyakit tanaman (Diperta NTB, 2013).

Penyakit layu fusarium disebabkan oleh jamur Fusarium oxysporum L., yang merupakan jamur tular tanah. Layu fusarium mudah dijumpai pada musim hujan, sehingga perlu tindakan preventif pada lahan dan tanaman. Tindakan preventif lebih dianjurkan karena lebih efektif dan biaya lebih murah bila dibandingkan dengan pengendalian setelah terjadi serangan (Diperta NTB, 2013).

Usaha petani mengendalikan penyakit layu fusarium, dengan memberikan kapur dolomit pada lahan sebelum tanam, dan ada juga dengan pestisida kimia. Namun belum mengatasi permasalahan terhadap penyakit layu fusarium. Pemberian pestisida kimia terus menerus berdampak pada lingkungan dan residu pada hasil bawang merah. Ada beberapa cara untuk mengendalikan penyakit layu fusarium. Di antaranya dengan penggunaan PGPR (Plant Growth Promoting Rhizobacteria) dan dengan menggunakan agensia hayati dari jamur Trichoderma spp. PGPR adalah bakteri perakaran pemacu pertumbuhan tanaman. Kombinasi antara bakteri Bacillus polymixa dan Pseudomonas flourencens yang dapat menekan perkembangan OPT serta meningkatkan ketersediaan nutrisi bagi tanaman (Diperta NTB, 2013 ).

Agensia Hayati merupakan Pengendali 
Hayati (Biological Control Agens), setiap organisme meliputi spesies, subspesies, varietas, semua jenis serangga, nematoda, protozoa, cendawan (fungi), bakteri, virus, mikoplasma serta organisme lainnya. Agensia hayati dalam semua tahap perkembangannya dapat digunakan untuk keperluan pengendalian hama, penyakit tanaman atau organisme pengganggu dalam proses produksi dan pengolahan hasil pertanian (Sunarno, 2014). Penggunaan agensia hayati ini nanti diharapkan menghasilkan pertanian yang berkelanjutan yang berorientasi kepada kelestarian lingkungan dan meningkatkan hasil pertanian (Prabaningrum, 2015). Dalam rangka meningkatkan pertumbuhan dan hasil bawang merah dapat digunakan PGPR yang merupakan bakteri pemicu pertumbuhan. PGPR memproduksi fitohormon yang dibutuhkan oleh pertumbuhan tanaman, serta kombinasi antara bakteri Bacillus polymixa L. dan Pseudomonas flourencens L. yang dapat menurunkan perkembangan OPT serta meningkatkan ketersediaan nutrisi tanaman.

PenggunaanagensiahayatiTrichoderma spp dan PGPR dengan tepat konsentrasi diharap dapat merangsang pertumbuhan dan meningkatkan hasil serta menekan perkembangan penyakit pada tanaman bawang merah. Keberadaan OPT menjadi kendala dalam berbudidaya tanaman bawang merah. Penggunaan agensia hayati yang ramah lingkungan diharapkan menghasilkan bawang merah yang aman konsumsi. Pengendalian penyakit dengan menggunakan agensia hayati dari jamur Trichoderma $s p$. dan PGPR dengan berbagai konsentrasi perlu dicoba karena dapat menjadi parasit jamur penyebab penyakit tanaman. Tujuan penelitian ini adalah mengetahui interaksi dosis dan konsentrasi agen hayati terhadap pertumbuhan dan hasil bawang merah serta efikasi terhadap intensitas penyakit pada tanaman bawang merah, pengaruh dosis penggunaan agensia hayati Trichoderma $s p$ terhadap pertumbuhan, hasil bawang merah, dan penyakit pada tanaman bawang merah, konsentrasi PGPR yang tepat untuk pertumbuhan dan hasil bawang merah serta terhadap penyakit pada tanaman bawang merah. Diduga Agens hayati Trichoderma harsianum L. dosis $50 \mathrm{~kg}$ per hektar dengan pemberian PGPR konsentrasi $2 \%$ (20 ml per 1 air) dapat menurunkan serangan penyakit, memberikan pertumbuhan dan hasil tanaman bawang merah terbaik.

\section{METODE PENELITIAN}

Penelitian dilaksanakan di lahan sawah desa Pandowan, Kecamatan Galur Kabupaten Kulon Progo dengan ketinggian $8 \mathrm{~m}$ dpl, suhu rata-rata $22-31^{\circ} \mathrm{C}$, kelembaban udara relatif rata-rata $82,2 \%$, dan intensitas cahaya rata-rata 45,5\%. Jenis tanah grumusol dengan pH tanah 5,5- 6,7. Penelitian dilaksanakan mulai bulan Januari - Maret 2017. Penelitian merupakan percobaan faktorial $(2 \times 4)+1$, disusun dalam Rancangan Acak Kelompok Lengkap (RAKL) dengan 3 blok sebagai ulangan. Faktor pertama adalah dosis Trichoderma harsianum L. (T) yang terdiri atas 2 aras, yaitu: dosis Trichoderma harsianum L.0 kg/ha (T0) dan $50 \mathrm{~kg} / \mathrm{ha}$ atau setara dengan $5 \mathrm{mg} / \mathrm{m}^{2}$ (T1).Faktor kedua adalah: konsentrasi PGPR (P) yang terdiri atas 4 aras, yaitu: $0 \%$ atau tanpa PGPR (P0), $2 \%(\mathrm{P} 1), 4 \%(\mathrm{P} 2)$, dan $6 \%$ (P3). Ditambah satu perlakuan kontrol yaitu dengan 
pemberian fungisida kimia merk dagang Antracol konsentrasi $1 \%$.

Pelaksanaan penelitian meliputi: persiapan lahan dan pembuatan bedengan, persiapan bibit bawang merah, penanaman, pemeliharaan tanaman berupa penyulaman, pemupukan, penyiraman. Persiapan bahan agensia hayati. Trichoderma harsianum L. didapatkan dari Laboratorium UPTD BPTP Daerah Istimewa Yogyakarta.

Aplikasi dengan menyiapkan pupuk kandang sebanyak $20 \mathrm{~kg}$ dicampur dengan Trichoderma harsianum L., diaduk rata, didiamkan selama satu minggu ditutup dengan plastik. Setelah satu minggu diaplikasikan sesuai dengan perlakuan, satu petak sebanyak $1 \mathrm{~kg}$. Perlakuan PGPR. PGPR didapatkan dengan perbanyakan, yaitu tanah dan akar bambu $1 \mathrm{~kg}$, kaldu tulang sapi 6 liter, air cucian beras 2 liter, tetes tebu 1.5 liter, air matang dingin 7,5 liter. Cara Pembuatan tanah dan akar bambu direndam dalam 3 liter air selama 1 minggu. Kaldu tulang sapi, air cucian beras, tetes tebu dicampur, direbus sampai mendidih. Kemudian didinginkan. Setelah dingin dituang ke galon aqua.Tambahkan air rendaman akar bambu yang sudah disaring dengan air matang dingin sampai menjadi 20 liter. Fermentasi bahan PGPR selama satu minggu, galon ditutup dan dipasang alat aerator digunakan sampai 7 hari. Pengendalian pathogen pada tanaman bawang merah dilakukan secara preventif. Perlakuan agensia hayati, yaitu penggunaan Trichoderma harsianum dan PGPR sesuai aras. Trichoderma harsianumm L dosis $0 \mathrm{~kg} / \mathrm{ha}$ (T0) yaitu pupuk kandang tanpa Trichoderma harsianum $\mathrm{L}$ dan T1 Pupuk kandang yang telah dicampur dengan Trichoderma harsianum L $50 \mathrm{~kg} /$ ha atau $5 \mathrm{mg} / \mathrm{m} 2$ ) diberikan sebelum tanam saat pengolahan tanah. PGPR sesuai aras perlakuan, pemberian dengan penyiraman pada tanah sebelum tanam, dan dilanjutkan setiap minggu sekali (sebanyak 6 kali) sampai tanaman berumur 45 hari setelah tanam (hst). Volume penyiraman campuran air dan PGPR pada petak perlakuan disesuaikan dengan umur tanaman (kurang lebih $2000 \mathrm{ml}$ ) dengan konsentrasi PGPR sesuai dengan perlakuan. Petak kontrol menggunakan fungisida kimia sebanyak tiga kali pemberian, yaitu pada umur 7, 20, dan 30 hst. Pestisida kimia Antraol konsentrasi $1 \%$. Volume semprot disesuaikan dengan umur tanaman. Pengendalian pada gulma dilakukan setiap ada gulma secara mekanik yaitu dengan mencabut secara langsung kemudian dibuang di luar lahan. Panen dilakukan setelah tanaman berumur 60 hst.

Variabel yang diamati dalam penelitian ini adalah pertumbuhan tanaman meliputi: tinggi tanaman, jumlah daun, jumlah anakan, bobot umbi segar per rumpun, bobot umbi kering per rumpun. Hasil Tanaman, pengukuran dilakukan setelah panen, meliputi: bobot umbi segar per petak, bobot umbi kering per petak, bobot umbi segar per hektar, bobot umbi kering per hektar. Efikasi OPT dengan menghitung Intensitas serangan penyakit. Intensitas serangan penyakit dapat ditentukan dengan perhitungan sebagai berikut: kerusakan mutlak untuk menilai serangan penyakit layu fusarium yang menyebabkan kerusakan mutlak atau dianggap mutlak digunakan rumus sebagai berikut (Dirjen Hortikultura, 2002) : 


$$
I=\frac{a}{a+b} \times 100 \%
$$

Keterangan:

$\mathrm{I}=$ Intensitas serangan $(\%)$

$\mathrm{a}=$ Banyaknya contoh (daun, pucuk, bunga, buah,tunas, tanaman, rumpun tanaman) yang rusak mutlak atau dianggap rusak mutlak

$\mathrm{b}=$ Banyaknya contoh yang tidak rusak (tidak menunjukkan gejala serangan)

- Kerusakan tidak mutlak

Untuk menilai serangan penyakit busuk daun dan bercak ungu yang tidak menimbulkan kerusakan mutlak digunakan rumus sebagai berikut (Dirjen Hortikultura, 2002) :

$$
\mathrm{I}=\frac{\sum_{i=0}^{Z}(\mathrm{ni} \mathrm{x} \mathrm{Vi})}{\mathrm{Z} x \mathrm{~N}} \times 100 \%
$$

Keterangan:

$\mathrm{I}=$ Intensitas serangan

$\mathrm{ni}=$ Jumlah tanaman atau bagian tanaman contoh dengan skala kerusakan vi

$\mathrm{Vi}=$ Nilai skala kerusakan contoh ke-i

$\mathrm{N}=$ Jumlah tanaman atau bagian tanaman contoh yang diamati

$\mathrm{Z}=$ Nilai skala kerusakan tertinggi

Analisis data pengamatan untuk mengetahui pengaruh perlakuan dengan menggunakan sidik ragam (Analysis of Variance) pada jenjang nyata 5\%. Apabila pada sidik ragam peubah memberikan pengaruh nyata dilakukan uji lebih lanjut dengan DMRT (Duncan'ss Multiple Range Test) pada taraf uji 5\% untuk mengetahui beda rerata perlakuan.

\section{HASIL DAN PEMBAHASAN}

Hasil pengamatan pada setiap variabel yang telah dianalisis sidik ragam dan DMRT disajikan dalam tabel 1,2 dan 3.
Efikasi dosis Trichoderma harsianum dan konsentrasi PGPR pada tanaman bawang merah terjadi interaksi terhadap variabel pertumbuhan tinggi tanaman dan jumlah daun, variabel intensitas serangan penyakit busuk daun, dan intensitas serangan penyakit bercak ungu (Tabel 1). Pada variabel pertumbuhan jumlah anakan, bobot segar per rumpun, dan bobot kering per rumpun tidak terjadi interaksi (Tabel 2). Variabel hasil bobot segar per petak, bobot kering per petak, bobot segar per hektar, bobot kering per hektar tidak terjadi interaksi. Variabel intensitas serangan penyakit layu Fusarium tidak terjadi interaksi (Tabel 3).

Variabel pertumbuhan tinggi tanaman (Tabel 1) perlakuan tanpa Trichoderma dan PGPR $4 \%$ berbeda nyata menghasilkan tinggi tanamn tertinggi yaitu32,722 $\mathrm{cm}$ berbeda nyata dengan perlakuan Trichoderma, PGPR 4\% dan kontrol . Perlakuan PGPR konsentrasi $0 \%, 2 \%, 4 \%$ dan $6 \%$ menghasilkan tinggi tanaman bawang merah tidak berbeda nyata. Hal ini sesuai dengan hasil penelitian Febriyanti et al. (2015) perlakuan semua kombinasi bakteri PGPR, Bacillus subtilis, Pseudomonas fluorescens mampu meningkatkan pertumbuhan kacang tanah. Pseudomonas fluorescens menghasilkan hormon tanaman, yaitu asam salisilat dan asam indol asetat (IAA) yang merupakan bioaktif dan merangsang perpanjangan akar (Santoso, 2007). Tinggi tanaman cabai rawit dengan perlakuan PGPR P. fluorescens dan Azotobacter sp. dapat mencapai 69,25 cm PGPR P. fluorescens dan B. subilis dapat meningkatkan rerata bobot buah cabai rawit hingga 2,17 gram per tanaman (A'yun et al, 2013). 
Tabel 1. Tinggi tanaman, jumlah daun, dan intensitas serangan busuk daun pada umur 35 dan 42 hst

\begin{tabular}{|c|c|c|c|c|c|}
\hline Perlakuan & $\begin{array}{l}\text { Tinggi } \\
\text { tanaman } \\
\text { pada umur } \\
42 \text { hst }(\mathrm{cm})\end{array}$ & $\begin{array}{l}\text { Jumlah daun } \\
\text { pada umur } \\
42 \text { hst (helai) }\end{array}$ & $\begin{array}{l}\text { Intensitas } \\
\text { serangan } \\
\text { penyaki busuk } \\
\text { daun pada } \\
\text { umur } 35 \text { hst (\%) }\end{array}$ & $\begin{array}{l}\text { Intensitas } \\
\text { serangan } \\
\text { penyaki busuk } \\
\text { daun pada pada } \\
\text { umur } 42 \text { hst (\%) }\end{array}$ & $\begin{array}{l}\text { Intensitas } \\
\text { serangan } \\
\text { penyakit } \\
\text { bercak ungu } \\
(\%)\end{array}$ \\
\hline $\begin{array}{l}\text { Trichoderm } 0 \mathrm{Kg} / \text { ha dengan } \\
\text { PGPR 0\% (T0P0) }\end{array}$ & $29,96 \mathrm{ab}$ & $21,11 \mathrm{ab}$ & $5,82 \mathrm{~g}$ & $12,6 \mathrm{f}$ & $0,2 \mathrm{c}$ \\
\hline $\begin{array}{l}\text { Trichoderm } 0 \mathrm{Kg} / \text { ha dengan } \\
\text { PGPR } 2 \% \text { (T0P1) }\end{array}$ & $30,62 \mathrm{ab}$ & $22,77 \mathrm{ab}$ & $8,61 \mathrm{e}$ & $15,2 \mathrm{~d}$ & $0 \mathrm{c}$ \\
\hline $\begin{array}{l}\text { Trichoderm } 0 \mathrm{Kg} / \text { ha dengan } \\
\text { PGPR 4\% (T0P2) }\end{array}$ & $32,72 \mathrm{a}$ & $27,55 \mathrm{a}$ & $11,84 \mathrm{c}$ & $14,35 \mathrm{de}$ & $0,46 \mathrm{bc}$ \\
\hline $\begin{array}{l}\text { Trichoderm } 0 \mathrm{Kg} / \text { ha dengan } \\
\text { PGPR 6\% (T0P3) }\end{array}$ & $27,61 \mathrm{abc}$ & $20,55 \mathrm{ab}$ & $20,4 \mathrm{a}$ & $20,17 \mathrm{a}$ & $0 \mathrm{c}$ \\
\hline $\begin{array}{l}\text { Trichoderm } 50 \mathrm{Kg} / \text { ha dengan } \\
\text { PGPR } 0 \%(\mathrm{~T} 1 \mathrm{P} 0)\end{array}$ & $29,27 \mathrm{ab}$ & $27,22 \mathrm{a}$ & $5,34 \mathrm{~g}$ & $13,71 \mathrm{e}$ & $0,2 \mathrm{c}$ \\
\hline $\begin{array}{l}\text { Trichoderm } 50 \mathrm{Kg} / \text { ha dengan } \\
\text { PGPR 2\% (T1P1) }\end{array}$ & $26,55 \mathrm{abc}$ & $17,55 \mathrm{ab}$ & $8,51 \mathrm{e}$ & $18,05 \mathrm{~b}$ & $1,53 \mathrm{a}$ \\
\hline $\begin{array}{l}\text { Trichoderm } 50 \mathrm{Kg} / \text { ha dengan } \\
\text { PGPR 4\% (T1P2) }\end{array}$ & $25,54 b c$ & $18,77 \mathrm{ab}$ & $13,22 \mathrm{~b}$ & $17,10 \mathrm{c}$ & $1,0 \mathrm{a}$ \\
\hline $\begin{array}{l}\text { Trichoderm } 50 \mathrm{Kg} / \text { ha dengan } \\
\text { PGPR 6\% (T1P3) }\end{array}$ & $29,45 \mathrm{ab}$ & $21,55 \mathrm{ab}$ & $6,83 \mathrm{f}$ & $17,9 \mathrm{bc}$ & $0 \mathrm{c}$ \\
\hline Rerata & $28,8 \times$ & $22,13 \mathrm{x}$ & $10 \mathrm{x}$ & $16,13 \mathrm{x}$ & $0,42 \times$ \\
\hline Kontrol (Pestisida kimia) & $21,66 y$ & $14,55 \mathrm{y}$ & $10,7 \times$ & $14,36 \mathrm{y}$ & $0 \mathrm{y}$ \\
\hline BNT $5 \%$ & $(+)$ & $(+)$ & $(+)$ & $(+)$ & $(+)$ \\
\hline
\end{tabular}

Keterangan: Rerata yang diikuti oleh huruf sama pada kolom yang sama menunjukkan tidak ada beda nyata pada uji DMRT 5\%

$(+)$ : ada interaksi

Tabel 2. Jumlah anakan per rumpun, umbi segar per rumpn, umbi kering per rumpun, umbi segar per petak, umbi kering per petak, umbi segar per hektar, dan umbi kering per hektar.

\begin{tabular}{llllllll}
\hline perlakuan & $\begin{array}{l}\text { Jml } \\
\text { anakan }\end{array}$ & $\begin{array}{l}\text { Umbi segar/ } \\
\text { rumpun (g) }\end{array}$ & $\begin{array}{l}\text { Umbi } \\
\text { kering/rum- } \\
\text { pun (g) }\end{array}$ & $\begin{array}{l}\text { Umbi } \\
\text { segar/pet- } \\
\text { tak (g) }\end{array}$ & $\begin{array}{l}\text { Umbi } \\
\text { kering/ } \\
\text { petak (g) }\end{array}$ & $\begin{array}{l}\text { Umbi } \\
\text { segar/ha } \\
(\mathrm{kg})\end{array}$ & $\begin{array}{l}\text { Umbi ker- } \\
\text { ing/ha (kg) }\end{array}$ \\
\hline $\begin{array}{l}\text { Trichoderma 0 } \\
\text { Kg/ha (T0) }\end{array}$ & $8,33 \mathrm{a}$ & $0,038 \mathrm{a}$ & $0,03 \mathrm{a}$ & $0,11 \mathrm{a}$ & $0,08 \mathrm{a}$ & $15,95 \mathrm{a}$ & $9,69 \mathrm{a}$ \\
Trichoderma 50 & $7,61 \mathrm{a}$ & $0,035 \mathrm{a}$ & $0,026 \mathrm{a}$ & $0,14 \mathrm{a}$ & $0,11 \mathrm{a}$ & $13,17 \mathrm{a}$ & $12,25 \mathrm{a}$ \\
Kg/ha (T1) & & & & & & & \\
PGPR 0\% (P0) & $8,7 \mathrm{p}$ & $0,042 \mathrm{p}$ & $0,03 \mathrm{p}$ & $0,12 \mathrm{p}$ & $0,09 \mathrm{p}$ & $14,33 \mathrm{p}$ & $10,05 \mathrm{p}$ \\
PGPR 2 \% (P1) & $7,16 \mathrm{p}$ & $0,034 \mathrm{pq}$ & $0,026 \mathrm{p}$ & $0,14 \mathrm{p}$ & $0,1 \mathrm{p}$ & $15,7 \mathrm{p}$ & $12,037 \mathrm{p}$ \\
PGPR 4 \% (P2) & $7,5 \mathrm{p}$ & $0,033 \mathrm{pq}$ & $0,026 \mathrm{p}$ & $0,1 \mathrm{p}$ & $0,08 \mathrm{p}$ & $11,29 \mathrm{p}$ & $9,11 \mathrm{p}$ \\
PGPR 6 \% (P3) & $8,44 \mathrm{p}$ & $0,037 \mathrm{pq}$ & $0,03 \mathrm{p}$ & $0,15 \mathrm{p}$ & $0,114 \mathrm{p}$ & $16,92 \mathrm{p}$ & $12,7 \mathrm{p}$ \\
Rerata & $7,96 \mathrm{x}$ & $0,036 \mathrm{x}$ & $0,028 \mathrm{x}$ & $0,12 \mathrm{x}$ & $0,09 \mathrm{x}$ & $14,56 \mathrm{x}$ & 10,97 \\
Kontrol & $6,66 \mathrm{x}$ & $0,024 \mathrm{y}$ & $0,019 \mathrm{x}$ & $0,07 \mathrm{x}$ & $0,07 \mathrm{x}$ & $7,9 \mathrm{y}$ & 7,33 \\
BNT 5 \% & $(-)$ & $(-)$ & $(-)$ & $(-)$ & $(-)$ & - & - \\
\hline
\end{tabular}

Keterangan: Rerata yang diikuti oleh huruf sama pada kolom yang sama menunjukkan tidak ada beda nyata pada uji DMRT 5\%

(-): Tidak ada interaksi 
Tabel 4. Intensitas serangan layu fusarium umur 21 hst, 28 hst, 35 hst

\begin{tabular}{llll}
\hline perlakuan & $\begin{array}{l}\text { Intensitas serangan } \\
\text { layu fusarium umur } \\
21 \mathrm{hst}\end{array}$ & $\begin{array}{l}\text { Intensitas serangan layu } \\
\text { fusarium umur 28 hst }\end{array}$ & $\begin{array}{l}\text { Intensitas serangan layu } \\
\text { fusarium umur 35 hst }\end{array}$ \\
\hline $\begin{array}{l}\text { Trichoderma } \\
\text { 0 Kg/ha (T0) }\end{array}$ & $9,02 \mathrm{~b}$ & $11,11 \mathrm{~b}$ & $12,84 \mathrm{ab}$ \\
Trichoderma & $7,9 \mathrm{~b}$ & $9,72 \mathrm{~b}$ & $9,72 \mathrm{~b}$ \\
$50 \mathrm{Kg} / \mathrm{ha}$ (T1) & & & \\
PGPR 0\% (P0) & $4,16 \mathrm{p}$ & $5,55 \mathrm{p}$ & $5,55 \mathrm{q}$ \\
PGPR 2 \% (P1) & $9,72 \mathrm{p}$ & $11,11 \mathrm{p}$ & $11,11 \mathrm{p}$ \\
PGPR 4 \% (P2) & $7,63 \mathrm{p}$ & $11,11 \mathrm{p}$ & $11,11 \mathrm{p}$ \\
PGPR 6 \% (P3) & $12,49 \mathrm{p}$ & $13,88 \mathrm{p}$ & $17,36 \mathrm{p}$ \\
Rerata & $8,46 \mathrm{y}$ & $10,41 \mathrm{y}$ & $11,28 \mathrm{y}$ \\
Kontrol & $19,44 \mathrm{x}$ & $20,83 \mathrm{x}$ & $20,83 \mathrm{x}$ \\
BNT 5\% & $(-)$ & $(-)$ & $(-)$ \\
\hline
\end{tabular}

Keterangan : Rerata yang diikuti oleh huruf dan pada kolom yang sama menunjukkan tidak ada beda nyata pada uji DMRT 5\%

( - ) : Tidak ada interaksi

Variabel jumlah daun tanaman bawang merah terjadi interaksi (Tabel 1). Pada kombinasi perlakuan tanpa Trichoderma dengan PGPR $4 \%$ menghasilkan jumlah daun tertinggi yaitu 27,556 dan rerata kombinasi perlakuan nyata lebih tinggi dibandingkan dengan perlakuan penggunaan pestisida kimia. Perlakuan PGPR konsentrasi $0 \% .2 \%, 4 \%, 6 \%$, tanpa Trichoderma dan dengan Trichoderma menghasilkan jumlah daun tanaman bawang merah tidak berbeda nyata. Hal ini sesuai dengan hasil penelitian Santoso (2007) Pseudomonas fluoerescense L. didalam PGPR menghasilkan hormon tanaman, yaitu asam salisilat dan asam indol asetat (IAA) yang merupakan bioaktif dan merangsang pertumbuhan akar. Pada awal pertumbuhan umur $7-28$ hst intensitas serangan busuk daun kurang dari $10 \%$, hal ini memungkinkan pertumbuhan daun berjalan dengan baik, serangan penyakit busuk daun tidak mempengaruhi pertumbuhan daun. Penggunaan Trichoderma dan PGPR terjadi interaksi terhadapjumlah daun bawang merah.
Trichoderma harsianum L. menghasilkan enzim kitinase dan $\beta$ 1.3-glukanase yang berfungsi melarutkan dinding sel patogen, dengan proses antagonis parasitisme. Trichoderma harsianum L. mempunyai kemampuan untuk mengendalikan penyakit layu dan bercak daun yang menyerang tanaman pada fase pembibitan atau di lahan pertanaman. Manfaat lain cendawan ini adalah membuat tanaman lebih vigor, meningkatkan ketahanan tanaman, berfungsi sebagai dekomposer yang dapat memperbaiki kesuburan tanah (Diperta BPTP DIY, 2011).

Penggunaan PGPR juga meningkatkan pertumbuhan tanaman. Aplikasi PGPR dengan perendaman benih dan penyiraman pada bawang merah untuk pertumbuhan bawang merah (Diperta NTB, 2013). Konsentrasi PGPR tidak beda nyata. Sesuai dengan penelitian perendaman bibit krisan dan benih tanaman sayuran (kacang panjang, tomat, bawang merah, dan mentimun) serta penyiraman tanaman krisan dan tanaman sayuran dengan PGPR konsentrasi $20 \mathrm{ml} / \mathrm{L}$ 
air meningkatkan pertumbuhan tanaman (Ngadiran, 2013). Perlakuan PGPR $P$. fluorescens dan Azotobacter sp. dapat menurunkan intensitas serangan TMV pada tanaman cabai rawit hingga 89,92\%. Tinggi tanaman cabai rawit dengan perlakuan PGPR P. fluorescens dan Azotobacter sp. dapat mencapai 69,25 cm PGPR P. fluorescens dan B. subilis dapat meningkatkan rerata bobot buah cabai rawit hingga 2,17 gram per tanaman (A'yun et al, 2013).

PGPR sebagai biofertilizer, meningkatkan penyerapan unsur $\mathrm{N}$ oleh PGPR pemfiksasi nitrogen, meningkatkan kemampuan pengambilan unsur besi $\left(\mathrm{Fe}^{3+}\right)$ oleh PGPR penghasil siderofor, meningkatkan kemampuan penyerapan unsur S oleh PGPR pemfiksasi sulfur, meningkatkan ketersediaan unsur $\mathrm{P}$ oleh PGPR pelarut fosfat, dan meningkatkan ketersediaan unsur $\mathrm{Mn}^{2+}$. Soesanto et al (2008) menyatakan bahwa bakteri P. fluorescens dalam PGPR dapat memberikan pengaruh menguntungkan terhadap perkembangan dan pertumbuhan tanaman.

Efikasi macam dan konsentrasi agen hayati pada tanaman bawang merah umur $7-42$ hst ada interaksi terhadap variabel intensitas serangan busuk daun dan intensitas serangan bercak daun (Tabel 1). Pada awal pertumbuhan umur $7-28 \mathrm{hst}$ intensitas serangan busuk daun kurang dari $10 \%$. Tanaman bawang merah mulai umur 35 dan 45 hst terjadi peningkatan intensitas serangan. Efikasi tertinggi pada perlakuan dengan penggunaan Trichoderma PGPR 0 $\%$, yaitu dengan intensitas serangan 5,34\% , urutan kedua perlakuan tanpa Trichoderma PGPR 0\% yaitu 5,82\% disusul perlakuan dengan penggunaan Trichoderma PGPR $6 \%$ yaitu 6,83\%. Perlakuan tanpa Trichoderma, PGPR $0 \%$ dan dengan Trichoderma PGPR $0 \%$ beda nyata dan terendah dibanding dengan perlakuan tanpa Trichoderma PGPR $2 \%$, tanpa Trichoderma PGPR $4 \%$, tanpa Trichoderma PGPR $6 \%$ maupun dengan Trichoderma PGPR $2 \%$, PGPR 4 \%, PGPR 6 $\%$. Rerata kombinasi perlakuan tidak berbeda dengan perlakuan pemberian pestisida kimia.

$$
\text { Perlakuan penggunaan dosis }
$$

Trichoderma dan konsentrasi PGPR ada interaksi terhadap intensitas serangan busuk daun tanaman bawang merah umur 42 hst (Tabel 1). Efikasi tertinggi pada perlakuan tanpa Trichoderma konsentrasi PGPR $0 \%$, berbeda dan nyata lebih rendah dibanding dengan kombinasi perlakuan tanpa Trichoderma PGPR $2 \%$, tanpa Trichoderma PGPR $4 \%$, tanpa Trichoderma PGPR $6 \%$ maupun dengan Trichoderma PGPR $0 \%$, PGPR $2 \%$, PGPR $4 \%$, PGPR $6 \%$. Rerata kombinasi perlakuan berbeda dan lebih tinggi intensitasnya dibanding dengan pemberian pestisida kimia.

Penggunaan pestisida kimia cukup efektif dalam menekan serangan penyakit busuk daun. Namun dengan penggunaan pestisida kimia terus menerus akan berdampak negatif pada lingkungan di sekitar tanaman maupun pada hasil tanaman. Sifat fisik, sifat kimia dan sifat biologi pada tanah ada kecenderungan turun kualitasnya. Ekologi di lingkungan tanaman tidak seimbang, banyak musuh alami yang berguna bagi tanaman ikut mati. Penggunaan pestisida kimia terus menerus akan meningkatkan residu pestisida pada hasil tanaman (Miskiyah, 2009). Untuk mengurangi ketergantungan petani pada 
penggunaan pestisida kimia, maka bisa digunakan agensia hayati baik dari golongan jamur, bakteri maupun virus (Sunarno, 2012).

Serangan penyakit busuk daun ini umumnya meningkat dan menyebar dengan cepat terutama pada musim hujan. Penelitian dilakukan pada bulan Januari, intensitas hujan yang tinggi menyebabkan meningkatnya serangan pada tanaman bawang merah. Penyakit busuk daun disebabkan cendawan Peronospora destructor ini menunjukkan gejala awal berupa bercak hijau pucat di dekat ujung daun. Daun segera menguning, layu dan mengering. Penyakit tersebut menyebar dengan cepat sewaktu musim hujan dengan udara lembap dan suhu yang rendah pada malam hari.

Penyakit Alternaria porii pada perlakuan penggunaan Trichoderma, PGPR $2 \%$ dan penggunaan Trichoderma PGPR 4 $\%$ menghasilkan intensitas serangan tertinggi yaitu $1,53 \%$ dan $1 \%$ beda nyata lebih tinggi dengan semua perlakuan. Intensitas serangan kategori ringan, sehingga tidak mempengaruhi terhadap pertumbuhan tanaman.

Sidik ragam menunjukan tidak terjadi interaksi pengaruh antara perlakuan dosis dan konsentrasi agen hayati PGPR terhadap jumlah anakan, bobot basah per rumpun, bobot basah per hektar, bobot kering perhektar (Tabel 2) dan intensitas serangan layu Fusarium (Tabel 3). Semua perlakuan kombinasi menunjukkan saling tidak beda nyata. Hal ini diduga pemberian salah satu agens hayati berupa Trichoderma dosis terlalu kecil. Hasil Penelitian Shofiyani dan Suyadi (2014) menyatakan dosis Trichoderma 40 g per lubang tanam pada bawang merah memberikan pengaruh terbaik terhadap pertumbuhan dan hasil bawang merah (bobot umbi per rumpun 29,63 g). Tanaman bawang merah diduga kekurangan unsur hara makro Nitrogen $(\mathrm{N})$ dan Kalium (K). Hal ini disebabkan karena kurangnya masukan pupuk ke tanaman karena pada penelitian ini pemupukan susulan hanya dilakukan satu kali yaitu umur 14 hst. Pada budidaya tanaman bawang merah banyak membutuhkan pupuk sebagai nutrisi untuk pertumbuhannya, sehingga perlu dilakukan pemupukan $2-3$ kali untuk proses pertumbuhannya (Supriadi et al, 2013).

- Bobot umbi segar per rumpun hasil tertinggi perlakuan penggunaan PGPR $6 \%$ yaitu $0,046 \mathrm{~kg}$, bobot umbi segar per hektar hasil tertinggi perlakuan penggunaan PGPR $6 \%$ yaitu $23.741 \mathrm{~kg}$ per hektar dan bobot umbi kering per hektar hasil tertinggi pada perlakuan penggunaan PGPR 6\% yaitu 12.037 $\mathrm{kg}$ per hektar (Tabel 2). Meskipun diduga dosis Trichoderma per hektar kurang, namun dengan pemberian PGPR $6 \%$ diduga akan menambah bobot hasil pada tanaman bawang merah. Hasil Penelitian Wahyuningsih et al (2015) penggunaan PGPR dan urine kelinci menunjukkan adanya interaksi pada fase pertumbuhan tanaman parameter panjang tanaman, jumlah daun dan luas daun. Pada komponen hasil menunjukkan adanya interaksi pada parameter bobot segar umbi, bobot kering umbi matahari, diameter umbi dan produksi perhektar. Hal ini disebabkan PGPR sebagai biofertilizer, meningkatkan penyerapanunsurNolehPGPR, meningkatkan kemampuan pengambilan unsur besi $\left(\mathrm{Fe}^{3+}\right)$ oleh PGPR penghasil siderofor (untuk meningkatkan ketahanan tanaman) , meningkatkan kemampuan penyerapan unsur 
$\mathrm{S}$, meningkatkan ketersediaan unsur $\mathrm{P}$, meningkatkan ketersediaan unsur $\mathrm{Mn}^{2+}$.

Sidik ragam menunjukkan tidak terjadi interaksi antara perlakuan dosis penggunaan Trichoderma dan konsentrasi PGPR terhadap intensitas serangan layu fusarium umur 21, 28,35 hst pada tanaman bawang merah (Tabel 3). Serangan penyakit Layu Fusarium mulai terjadi pada umur 21 hst (Semangun, 2007). Perlakuan macam penggunaan Trichoderma maupun macam konsentrasi PGPR menghasilkan rerata intensitas serangan layu fusarium tidak berbeda, nyata lebih rendah dengan perlakuan penggunaan pestisida kimia. Perlakuan kontrol yaitu penggunaan pestisida kimia Antracol Intensitas serangan $20,83 \%$.

Trichoderma, $s p$ disamping sebagai organisme pengurai, dapat pula berfungsi sebagai agen hayati dan stimulator pertumbuhan tanaman. Trichoderma, $s p$ dapat menghambat pertumbuhan serta penyebaran racun jamur penyebab penyakit bagi tanaman seperti cendawan Rigdiforus lignosus, Fusarium oxysporum, Rizoctonia solani, Fusarium monilifome. Penggunaan pupuk biologis dan agen hayati Trichoderma, sp sangat efektif mencegah penyakit busuk pangkal batang, busuk akar yang menyebabkan tanaman layu, dan penyakit jamur akar putih. Penggunaan pupuk biologis dan biofungisida Trichoderma, $s p$ memang tidak memperlihatkan dampak manfaatnya secara langsung seperti pupuk ataupun fungisida kimia (Shofiyani et al., 2014 ).

Uji antagonisme secara in vitro menunjukkan bahwa jamur antagonis spesifik lokasi Trichoderma sp. berpotensi menghambat pertumbuhan jamur patogen Phytophthora infestans pada kentang (Purwantisari et al., 2009).

\section{KESIMPULAN}

1. Tidak terjadi interaksi antara dosis dan konsentrasi terhadap intensitas serangan layu fusarium, pertumbuhan variabel bobot kering per rumpun, dan hasil tanaman variabel bobot umbi kering perhektar. Interaksi terjadi pada tinggi tanaman, jumlah daun dan intensitas busuk daun. Kombinasi perlakuan tanpa Trichoderma konsentrasi PGPR $4 \%$ memberikan hasil tertinggi pada variabel tinggi tanaman dan jumlah daun.

2. Efikasi tertinggi untuk mengendalikan penyakit pada bawang merah kombinasi perlakuan tanpa penggunaan Trichoderma $s p$ dan konsentrasi PGPR $0 \%$.

3. Tanpa dan dengan pemberian Trichoderma memberikan pertumbuhan sama dibandingkan pestisida kimia.

4. Konsentrasi PGPR 0\% - $6 \%$ memberikan hasil sama terhadap hasil tanaman bobot umbi kering per hektar, nyata lebih tinggi dibandingkan dengan pestisida kimia.

\section{DAFTAR PUSTAKA}

A'yun, Hadiastono, Martosudiro., 2013. Pengaruh Penggunaan PGPR (Plant Growth Promoting Rhizobacteria) Terhadap Intensitas TMV (Tobacco Mosaic Virus), Pertumbuhan, dan Produksi Pada Tanaman Cabai (Capsicum frutescens L.). Jurnal HPT Unibraw 1 (1): 47-53.

Anonim, 2013. Data Pertanian Hortikultura. http://www.bps.go.id. Diakses 26 Januari 2015

Anonim, 2014. Pertanian Dalam Angka. 
www.kulonprogokab.go.id/V21/ pertanian 14 hal. Diakses 2 Maret 2016.

Anonim,, 2002. Metode Pengamatan OPT Tanaman Sayuran, Direktorat Perlindungan Hortikultura Dirjen Bina Produksi Hortikultura, Jakarta. 44 hal

Anonim,, 2004, Buku Pedoman Standar Prosedur Operasional (SPO) Budidaya Bawang Merah, Dirjen Bina Produksi Hortikultura, Jakarta. 56 hal

Anonim,, 2010. Standar Operasional Prosedur Budidaya Bawang Merah Kabupaten Nganjuk Jatim, Kementrian Pertanian Dirjen Hortikultura Direktorat Budidaya Tanaman sayuran dan Biofarmaka, Jakarta. 71 hal

Anonim, 2011. Jamur Antagonis Gliocladium sp dan T. Harsianum Pengendali Patogen Tular Tanah Parasit Tanaman, Dinas Pertanian Balai Proteksi Tanaman Pertanian Provinsi D.I Yogyakarta. 22 hal

Anonim,, 2013 . Perbanyakan Agens Hayati, Dinas Pertanian Pangan dan Hortikultura Provinsi Nusa Tenggara Barat. 15 hal.

Baswarsiati, 2009. Penerapan Teknologi Maju Budidaya Bawang Merah. https : ://baswarsiati.wordpress. com/2009/04/24/. Diakses 7 Maret 2015 jam 19.00 WIB

Batubara, 2013. Hama Penting Pada Tanaman Bawang Merah dan Pengendaliannya. $\quad \underline{\mathrm{http}} / / /$ rockypaulus.blogspot.com/2013/11/ hama penting pada tanaman. Diakses 25 Februari 2015

Girsang, 2009. Dampak Penggunaan Pestisida. https://usitani.wordpress. com/2009/02/26 dampak-negatifpenggunaan-pestisida. Diakses 2 Maret 2016.
Kafrawi, Zahraeni K., Muliani S., 2015. Skrining Isolat Plant Growth Promoting Rhizobacteri (PGPR). Prosiding Seminar Nasional Mikrobiologi Kesehatan dan Lingkungan. Makasar,29 Januari 2015. SBN 978-602-72245-0-6.

Nawangsari, 2010. Bawang Merah (Allium cepa L.). ccrc.farmasi.ugm.ac.id/ page.id=2170. Diakses 26 Januari 2016.

Ngadiran, 2013. PGPR (Plant Growth Promoting Rhizobacteria). Dinas Pertanian Balai Proteksi Tanaman Pertanian Daerah Istimewa Yogyakarta. 15 hal.

Nirwanto, 2011. Estimasi Kehilangan Hasil Ekonomi Produksi Bawang Merah Terhadap Penyakit Bercak Ungu. UPN "Veteran " Jawa Timur. 56 hal. Eprints.upnjatim.ac.id/3189/1/ Blinder_estimasi pdf. Diakses 2 Maret 2016.

Miskiyah, Munarso J. 2009. Kontaminasi Residu Pestisida pada Cabai Merah, Selada, dan Bawang Merah (Studi Kasus di Bandungan dan Brebes Jawa Tengan dan Cianjur Jawa Barat. Balai Besar Penelitian dan Pengembangan Pascapanen Pertanian. Jurnal Hort. 19(1) : 101 -111 ,

Prabaningrum, 2015.Empat Prinsip Dasar dalam Penerapan Pengendalian Hama Terpadu (PHT). http:// balitsalitbang.pertanian.go.id/ ind/index.php/beritaterbaru/378. Diakses 6 Desember 2015.

Purwantisari, Susiana and Hastuti, Rini Budi (2009) Uji Antagonisme Jamur Patogen Phytophthora infestans Penyebab Penyakit Busuk Daun dan Umbi Tanaman Kentang Dengan Menggunakan Trichoderma spp. Isolat Lokal. BIOMA, 11 (1). 24-32. ISSN 1410-8801. 
Putrasamedja dan Suwandi, 2004. Bawang Merah Indonesia. Balai Penelitian Tanaman Sayuran Lembang Bandung. 15 hal.

Santoso, S.E., L. Soesanto, dan T.A.D. Haryanto. 2007. Penekanan Hayati Penyakit Moler pada Bawang Merah dengan Trichoderma harzianum, Trochoderma konongii, dan Pseudomonas fluorescens P60. Jurnal HPT Tropika 7 (1): 53-61

Semangun, H. 2007. Penyakit-penyakit Tanaman Hortikultura di Indoneia, Gadjah Mada University Press, Yogyakarta. 850 hal.

Shofiyani A., Suyadi. 2014. Kajian Efektifitas Penggunaan Agensia Hayati Trichoderma sp. Untuk Mengendalikan Penyakit Layu Fusarium pada Tanaman Bawang Merah di Luar Musim. Prossiding Seminar Hasil Penelitian LPPM UMP 2014. ISBN 978 -602-149302-1.

Simatupang, 2004. Justifikasi dan Metode Penetapan Komoditas Strategis. pse.litbangpertanian.go.id/pdffiles/ Anjak 2004. Diakses 20 Februari 2016.
Soesanto, L., Rokhlani, dan Prihatiningsih N, 2008, Penekanan Beberapa Mikroorganisme Antagonis Terhadap Penyakit Layu Fusarium Gladiol, Jurnal Unsoed Agrafita 30(1):75-83

Sunarno, 2012. Pengendalian Hayati (Biologi Control) Sebagai Salah Satu Komponen Pengendalian Hama Terpadu (PHT). http:// journal.uniera.ac.id/pdf repository/ juniera31-uHihqla. Diakses 3 Maret 2016.

Supriadi, Rochdjatun, dan Jauhari. 2013. Kejadian Penyakit pada Tanaman Bawang Merah yang Dibudidayakan Secara Vertikultur di Sidoarjo. Jurnal HPT Vol. I, no 3, September 2013. ISSN: $338-356$.

Wahyuningsih, Herlina N., dan Setyono. 2015. Pengaruh Pemberian PGPR (Plant Growth Promoting Rizhobacteria) dan Pupuk Kotoran Kelinci Terhadap Pertumbuhan dan Hasil Tanaman. Jurnal 5( 8). Htpp://karya Ilmiah. fp. ub. Id/bp. Diakses 15 Desember 2015. 